\title{
Influence of Different Planting System and Levels of Nitrogen on Growth, Yield, Quality and Economics of Rice (Oryza sativa L.) - A Review
}

\author{
Divya Pyngrope, Prasad Mithare* and Gautam Ghosh
}

Department of Agronomy, Allahabad School of Agricultural, Sam Higginbottom University of Agriculture Technology \& Sciences, Allahabad - 211007, (Uttar Pradesh) India

*Corresponding author

\section{Keywords \\ Planting system, Nitrogen, Yield, Quality, Economics, Rice}

Article Info

Accepted:

14 December 2018

Available Online:

10 January 2019

\section{A B S T R A C T}

Cereals are the member of grasses, which belong to family Gramineae (Poaceae) and cultivated for edible components of their grain which is composed of the endosperm, germ and bran. Cereal grains are grown in greater quantities and provide more food energy worldwide than any other type of crop. In their natural form, they are a rich source of carbohydrates, protein, vitamins, minerals and fats. The green revolution of the 1970s resulted in remarkable increases in rice production. Since then the rate of production in most rice growing countries has slowed and has now reached a plateau. Contributing factor include a higher population growth rate and the conversion of some highly productive rice land for industrial and residential purpose. Millions of hectares in the humid regions of south and Southeast Asia are technically suited for rice production but are technically suited for rice production but are left uncultivated or are grown with very low yields because of salinity and abiotic stresses. Many research findings revels that System of Rice Intensification followed by $120 \mathrm{~kg}$ Nitrogen $\mathrm{ha}^{-1}$ has significantly perform better than all others planting system \& levels of nitrogen for various growth, yield \& quality attributes viz; Number of effective tillers hill ${ }^{-1}$ (18.59), Number of grains panicle ${ }^{-1}$ (108.88), Length of panicle $(27.90 \mathrm{~cm})$, Test weight $(24.82 \mathrm{~g})$, Grain yield $\left(5.34 \mathrm{t} \mathrm{ha}^{-1}\right)$, Straw yield $(10.26 \mathrm{t}$ $\left.\mathrm{ha}^{-1}\right)$, Harvest index $(34.23 \%)$ and Protein content $(8.37 \%)$. While the same combination also found prominent to obtain highest gross return $\left(152600.00 \mathrm{Rs} \mathrm{ha}^{-1}\right)$, net return $\left(92077.92 \mathrm{Rs} \mathrm{ha}^{-1}\right.$ ) and B: C ratio (2.52) respectively. This review article throws light on some important aspects on influence of different planting system and graded levels of nitrogen on growth, yield, quality and economics of rice (Oryza sativa L.). References from various research articles and literature were compiled systematically with respect to the topic. Evidence based research studies were also reviewed in this regard.

\section{Introduction}

Rice belongs to genus Oryza and the family Gramineae (Poaceae). The genus Oryza contains 25 recognized species, of which 23 are wild species and two cultivated (O. sativa and $O$. glaberrima). Rice is the staple food for more than $60 \%$ of the Indian population. Rice is India's pre-eminent crop, covering about one-fourth of the total cropped area and providing food to about half of the Indian population. In Asia alone, more than 2,000 million people obtain 60 to 70 per cent of 
their calories from rice and its products. Rice is mostly grown under submerged soil conditions and requires much more water compared with other crops. It accounts for about $43 \%$ of total food grain production and $46 \%$ of total cereal production in the country Anonymous et al., (2006). More than 90 per cent of the world's rice is produced and consumed in Asia, where it is an integral part of culture and tradition. Rice occupies a pivotal place in Indian agriculture and it is contributes to 15 per cent of annual GDP and provides 43 per cent calorie requirement for more than 70 per cent of Indians Anonymous et al., (2005). India has 44.14 million hectare area under rice and production of 106.65 million tonnes with an average yield of 2416 $\mathrm{kg} \mathrm{ha}^{-1}$ during 2013-14 (GOI (2015). Uttar Pradesh has an area of $5.98 \mathrm{~m}$ ha, production of 14.64 million tonnes and productivity of $2.447 \mathrm{t} \mathrm{ha}^{-1}$ of rice GOI (2015). It is estimated that 5000 liters of water is needed to produce $1 \mathrm{~kg}$ of Rice Bouman et al., (2009).

Manual transplanting is the most common practice of rice cultivation in south and southeast Asia. In recent years, water table is running down at a very rapid rate throughout the globe, thus sending an alarming threat and limiting the scope for cultivation of high water requiring crops very seriously. Rice being a crop having high water requirement, there is a need to search for alternative methods to reduce water requirement of rice without reduction in yield. Changes in crop establishment have important implications for farm operations, including primary tillage, seedbed preparation, planting, weeding, and water management that have a considerable impact on rice growth, especially seedling development and rice canopy structure establishment. Using a mechanical transplanter, seedlings are transplanted at uniform depth and spacing, thereby establishment of seedlings is faster and more number of tillers are produced (16.8 tillers hill $^{-1}$ ) which result in 30-35 per cent higher yield compared with hand transplanting Saha and Bharti (2010). Similarly Tiwari et al., (2003) reported that by using eight row selfpropelled rice transplanter save 68 per cent of labour compared to manual transplanting. The self-propelled eight row paddy transplanter saves $30 \mathrm{~mm}$ day $\mathrm{ha}^{-1}$ and eliminated drudgery on the part of laborers with the area of 1.5 ha in a day of 8 working hours Manjunatha et al., (2009). During the last two decades or so, a new approach, widely known as System of Rice Intensification (SRI), has attracted attention because of its apparent success in increasing rice yield. This system was introduced in India during the year 2000 as a viable alternative of rice cultivation that enhances the productivity while minimizing the inputs. Uphoff et al., (2002) Noticed that nutrient management must be sound for achieving yield potential of rice under System of Rice Intensification. SRI is a technique comprised of a set of practices and principles rather than as a "technology package" Uphoff et al., (2004). SRI is not a technology like that of high yielding varieties or a chemical fertilizer or insecticide. It is a system for managing plants, soil, water or nutrient together in mutually beneficial ways and creating synergies. System of Rice Intensification and management practices control or modify the microenvironment so that existing genetic potentials can be more fully expressed and realized. Nitrogen is a key component of many organic compounds. In the absence of applied nitrogen, the crop yield should be limited by the available nitrogen within the soil. Nitrogen application can improve the root system, so that water and nutrient absorption are facilitated. Yoshida et al., (1972) reported that nitrogen plays an important role in developing yield capacity and maintaining the photosynthetic activity during grain filling stage of the crop. Nitrogen application can improve the root system, so that water and nutrient absorption are 
facilitated and rice production and productivity was significantly enhanced with the introduction and cultivation of semidwarf, fertilizer responsive and non-lodging high yielding varieties in the early seventies leading to the "Green Revolution". Hence, efficient use and management of nitrogen in crop production is critical for obtaining optimum crop productivity, quality, environmental safety and economic returns. The objective of this study is to find the response of different planting system and graded levels of nitrogen on growth, yield, quality and economics of rice (Oryza sativa L.). The research prospects of this article will be helpful In future, it is important to develop the model and equipment of rice seedling and transplanting in different season and hybrid rice transplanting progress. Especially improve the technology of precision sowing, seedling gap filling, and seedling transplanting. In addition, it is necessary to improve the machine technology of fertilization, spraying, and weeding, and it is efficiently for rice production to combine the transplanting and fertilization. With the development of large-scale rice planting, it is important to invent the factory seedling progress, and socialized service system. In south India it is useful for double season, and single season rice seedling breeding, but it is small scaled nowadays. Seedling breeding technology for social service is further developing for rice production intensification and modernization.

Different planting system on growth, yield, quality and economics of rice

\section{System of rice intensification}

The SRI method of rice cultivation involves planting single seedling in wider row spacing i.e. $25 \mathrm{x} 25 \mathrm{~cm}$, which involves more labour intensive and laborious process. Mechanical equipments for various farm operations are generally being used by the farming community. Even small farmers are adopting and utilizing selected farm equipments for efficient farm management through custom hiring. Transplanting, weeding and harvesting are the major operations that consume most of the labour requirement in rice cultivation. Mechanization with SRI methods leads to maintain plant-to-plant spacing and reducing seedling age, reducing the seed requirements by $50 \%$, labor requirements reduction by $60 \%$, and the time required for all of the main rice-farming activities by $70 \%$. High labour demand during peak periods adversely affects timeliness of operation, thereby reducing the crop yield. Usage of tools, implements and machineries for puddling, transplanting, weeding and harvesting will lead to reduction in drudgery, cost and time. In SRI method the nursery was raised in raised bed and fourteen days old seedlings were planted at a spacing of $25 \times 25 \mathrm{~cm}$. Saina et al., (2001) reported in his research trial that SRI practice 50 tillers plant $^{-1}$ were easily obtained, and farmers who had mastered the methods and understand the principles were able to get over 100 tillers from single tiny seedling. Grain and straw yields were the highest (5.6 and $5.98 \mathrm{t} \mathrm{ha}^{-1}$ ) in SRI planting method.

The highest grain yield of SRI planting method was mostly the outcome of higher total number of tillers hill $^{-1}$, highest panicle length and highest number of grains panicle ${ }^{-1}$. Conventional planting method produced the lowest grain and straw yields (3.65 and $4.29 \mathrm{t}$ $\mathrm{ha}^{-1}$ ) respectively Hossain et al., (2003). The grain yield and water productivity were significantly increased at SRI planting with 14 days dapog seedlings planted at $25 \times 25$ cm spacing to achieve $7009,5655 \mathrm{~kg} \mathrm{ha}^{-1}$ and $0.610 \mathrm{~kg}$ and $0.494 \mathrm{~kg} \mathrm{~m}^{-3}$ of water respectively in wet and dry season Vijayakumar et al., (2006). SRI method of cultivation, application of FYM and RDF significantly increased the number of tillers. 
The treatment combinations with SRI method showed more number of productive tillers. Under SRI method, the days to $50 \%$ flowering and maturity were four to five days earlier compared to traditional method. 12 days old seedlings with wider spacing recorded significantly higher germination and vigour index values Krishna et al., (2008). Similarly findings are revealed by Rajeshwar and Khan (2008) in his experiment reported that highest grain yield of 6735 and $6125 \mathrm{~kg}$ $\mathrm{ha}^{-1}$ and water use efficiency of 6.75 and 6.25 $\mathrm{kg} \mathrm{ha}{ }^{-1} \mathrm{~mm}$ was recorded with green manuring and FYM under the SRI method of planting compared to the conventional method (6467 and 6053 and 4.50 and $4.25 \mathrm{~kg}$ $\left.\mathrm{ha}^{-1} \mathrm{~mm}\right)$. The combined effect of reduction in cost and higher yield has resulted in increase in net return to the extent of over $31 \%$. The average cost of production (paid out cost) has been worked out to be ₹ $269 \mathrm{q}^{-1}$ of rice under SRI practice and ₹ $365 \mathrm{q}^{-1}$ under normal practices, an advantage of $26 \%$ in cost of production Barah et al., (2009).

Maximum total grain productivity $(13750 \mathrm{~kg}$ $\left.\mathrm{ha}^{-1} \mathrm{yr}^{-1}\right)$, total fodder productivity $(14864 \mathrm{~kg}$ $\mathrm{ha}^{-1} \mathrm{yr}^{-1}$ ), net profit ( $₹ 79,912 \mathrm{ha}^{-1} \mathrm{yr}^{-1}$ ), gross returns ( $₹ 1,17.432 \mathrm{ha}^{-1} \mathrm{yr}^{-1}$ ), B:C ratio (2.13), total tillers $\left(412 \mathrm{~m}^{-2}\right)$ and effective tillers (343 $\mathrm{m}^{-2}$ ) were recorded with SRI method of paddy cultivation Hugar et al., (2009). The crop raised with SRI technique receiving recommended NPK + FYM at $10 \mathrm{t} \mathrm{ha}^{-1}$ registered yield superiority of 15.47 and $19 \%$ over farmers practice during 2006 and 2007 respectively Hussain et al., (2009). The considerable increase in rice productivity and farmer incomes, which is being achieved in Andhra Pradesh with substantial reduction in irrigation water application (162.3\%), labour and seed costs through utilization of SRI method of transplanting. Potential public savings on water $(51.5 \%)$ and power costs could be drawn upon not only for promoting SRI method of transplanting but also to effect systemic corrections in the irrigation sector, to mutual advantage Adusumilli et al., (2010). Similarly Barah et al., (2010) projected that the return to SRI is reasonably high at ₹ 14875 to ₹ $17629 \mathrm{ha}^{-1}$ (equivalent to US\$ 309 to US\$ 370) across the districts as compared to corresponding figure of ₹ 9263 to ₹ 14564 (US\$ 192 to US\$ 303) under conventional practices. Manjunatha et al., (2010) observed in research trial that younger seedlings of 9 days $\left(6.07 \mathrm{t} \mathrm{ha}^{-1}\right)$ and 12 days (6.01 $\mathrm{t} \mathrm{ha}^{-1}$ ) produced significantly higher grain yield than other aged seedlings, viz., 15 days

$(5.79$

$\left.\mathrm{ha}^{-1}\right), 18$ days $\left(5.77 \mathrm{t} \mathrm{ha}^{-1}\right)$ and 21 days $(5.78 \mathrm{t}$ $\left.\mathrm{ha}^{-1}\right)$. Modified SRI method of transplanting resulted in significantly higher grain yield $\left(6.34 \mathrm{t} \mathrm{ha}^{-1}\right)$ when compared to other methods, viz., normal method $\left(5.10 \mathrm{t} \mathrm{ha}^{-1}\right)$ and recommended SRI method of transplanting (6.21 t ha $\left.{ }^{-1}\right)$.

The experimental trial on rice conducted by Thakur et al., (2010) reported that performance of individual hills was significantly improved with wider spacing compared with closer spaced hills in terms of root growth and xylem exudation rates, leaf number and leaf sizes, canopy angle, tiller and panicle number, panicle length and grain number panicle ${ }^{-1}$, grain filling and 1000 grain weight and straw weight, irrespective of where SRI was employed. SRI yielded $40 \%$ more than the recommended practice. Priya $e t$ al., (2010) reported that adoption of SRI recorded 638 number of productive tillers $\mathrm{m}^{-}$ ${ }^{2}$ which was significantly higher than that of conventional method of rice cultivation (507). The length of panicle and numbers of grains panicle $^{-1}$ were also significantly higher under SRI than farmer's practice of rice cultivation. SRI registered 218 grains panicle ${ }^{-1}$ and 22.6 $\mathrm{cm}$ length of panicle. SRI registered a mean grain yield of $6082 \mathrm{~kg} \mathrm{ha}^{-1}$ which was significantly higher than conventional method of rice cultivation $\left(5223 \mathrm{~kg} \mathrm{ha}^{-1}\right)$. Thus 
significant superiority of SRI in terms of grain yield was evident due to 17.0 per cent yield increment by SRI. Veeraputhiran et al., (2008) also obtained 23.1 per cent yield improvement by SRI than farmers practice in Tamirabarani Command areas of Southern Tamil Nadu. The higher yield attributes like number of productive tillers $\mathrm{m}^{-2}$, length of panicle and numbers of grains panicle ${ }^{-1}$ attributed the higher grain yield of SRI. These results of higher grain yield with SRI collaborate with the findings of Makarim et al., (2002) and Ganesaraja et al., (2008). Similar results of higher yield attributes with SRI than conventional method were confirmed by (Kumar et al., (2002). Labour requirement for weeding was less in the conoweeded plots denoting lower cost of cultivation in SRI compared to other practices Anitha and Chellappan (2011).

System of rice intensification is a boon for small and marginal farmers as it reduced input cost of seeds by $60 \%$ and irrigation water cost by $40 \%$, reduced fertilizer cost by $30 \%$ and enhanced production by $35 \%$ over the traditional transplanted rice Karmakar et al., (2011). SRI practices showed significant response on root number, number of effective tillers hill $^{-1}$, days to flowering and harvest index Chapagain et al., (2011). The management factors followed in SRI method of cultivation produced significantly more number of panicles $\mathrm{m}^{-2}$ and number of grains panicle $^{-1}$, the yield was increased significantly by $18.6 \%$ when compared to conventional practices Prabha et al., (2011). In SRI method of transplanting recorded an additional grain yield $2.76 \mathrm{t} \mathrm{ha}^{-1}$ over normal transplanting (NTP) method due to more number of filled grains panicle ${ }^{-1}$ and better partitioning harvest index Sowmya et al., (2011). Similarly findings are given by Dass and Chandra (2012) reported that grain yield was $16.9 \%$ higher under SRI compared to conventional method $\left(5.22 \mathrm{t} \mathrm{ha}^{-1}\right)$. The experiment carried out on rice by Reddy et al., (2013) conclude that growing rice under SRI with 100\% NPK recorded significantly higher mean grain yield of $76.56 \mathrm{q} \mathrm{ha}^{-1}$ than transplanting with a grain yield of $64.76 \mathrm{q} \mathrm{ha}^{-1}$, resulting in a yield increase of $15 \%$. Shukla et al., (2014) recorded significantly higher growth attributes with transplanting of younger age seedling (10 days), viz. plant height, number of green leaves hill ${ }^{-1}$, dry matter accumulation with yield attributing characters. Similar results were confirmed by Duttarganvi et al., (2014) reported that significantly higher tillers hill $^{-1}(29)$, root length $(31 \mathrm{~cm})$, leaf area hill ${ }^{-1}$ $\left(319 \mathrm{~cm}^{2}\right)$, panicles hill' ${ }^{-1}(24)$ and grain yield $\left(5.63 \mathrm{t} \mathrm{ha}^{-1}\right)$ were recorded under SRI as compared to Normal Traditional Planting (NTP). The experiment finding of Pyngrope et al., (2017) revealed that SRI $+120 \mathrm{~kg}$ Nitrogen $\mathrm{ha}^{-1}$ significantly performed better than all other treatments viz; Number of effective tillers hill ${ }^{-1}$ (18.59), Number of grains panicle ${ }^{-1}$ (108.88), Length of panicle $(27.90 \mathrm{~cm})$, Test weight $(24.82 \mathrm{~g})$, Grain yield $\left(5.34 \mathrm{t} \mathrm{ha}^{-1}\right)$, Straw yield $\left(10.26 \mathrm{t} \mathrm{ha}^{-1}\right)$, Harvest index (34.23\%) and Protein content $(8.37 \%)$. SRI + $120 \mathrm{~kg}$ Nitrogen $\mathrm{ha}^{-1}$ recorded highest gross return (152600.00 Rs $\mathrm{ha}^{-1}$ ), net return (92077.92 $\left.\mathrm{Rs} \mathrm{ha}^{-1}\right)$ and B: C ratio (2.52), however treatment (MTR +120 $\mathrm{kg}$ Nitrogen ha ${ }^{-1}$ ), SRI $+60 \mathrm{~kg}$ Nitrogen ha ${ }^{-1}$, SRI + $90 \mathrm{~kg}$ Nitrogen $\mathrm{ha}^{-1}$ and SRI $+120 \mathrm{~kg}$ Nitrogen $\mathrm{ha}^{-1}$ were statistically at par with treatment SRI $+120 \mathrm{~kg}$ Nitrogen $\mathrm{ha}^{-1}$ respectively Pyngrope et al., (2018)

\section{Conventional transplanted rice}

Conventional paddy cultivation involves transplanting of seedlings in puddle fields performed by labours predominantly by women labours. Transplanting method involves seedbed preparation, nursery growing, care of seedlings in nursery, uprooting of seedlings, hauling and transplanting operations. The preparation of 
seedbed and sowing are done 30 days before planting. The rice farmers practicing transplanting are facing problems like shortage of labour during peak time, hike in labour charges, small and fragmented land holdings etc. The land was prepared conventionally and final land preparation was done by ploughing and cross ploughing by two wheel power tiller with two laddering before two days of transplanting. Raised bed and furrows were made manually by spade following the conventional land preparation. The crop was fertilized with $\mathrm{N}, \mathrm{P}, \mathrm{K}, \mathrm{S}$, and $\mathrm{Zn}$ at the rates of $100,60,40,10$, and $5 \mathrm{~kg} \mathrm{ha}$ ${ }^{1}$, respectively. In conventional method of rice cultivation, use of a seed rate of $30-60 \mathrm{~kg} \mathrm{ha}^{-1}$ in $1000 \mathrm{~m}^{-2}$ nursery area, seedling age $21-30$ days with $15 \times 10$ to $20 \times 15 \mathrm{~cm}$, irrigation 5 $\mathrm{cm}$ depth one day after disappearance of pounded water and manual weeding twice at 15 and 30 DAT were practiced.

\section{Machine transplanted rice}

Looking towards the labor shortage in the farm operations, government promotes mechanization in all the possible way to make the farming profitable. Due to small land holding and weak economic position, farmers are not in a position to purchase the machine individually, but on hiring basis the technology should be adopted. The mechanical transplanters are classified on the basis of nursery used i.e., machine using wash root seedling and machine using mat type seedlings. About $40 \%$ of the total energy requirement in mechanical transplanting was required in mat nursery preparation while energy share for traditional nursery under manual transplanting was only $11 \%$ Baruah et al., (2001). Mat type seedlings are raised on a polythene sheet with the help of frames. 2030 days old seedlings were found most suitable for transplanting. The mat thickness for best results should be about $2 \mathrm{~cm}$. Transplanting mat type seedling is becoming more popular due to its superior performance and reduced labor requirement of $50 \mathrm{man} \mathrm{ha}^{-1}$ Dixit et al., (2012). The use of self-propelled transplanter gives economic benefits to the farmers over the manual transplanting methods. The average net returns were Rs. 19,798.00 ha ${ }^{-1}$ and Rs. 27,462.00 ha ${ }^{-1}$ in traditional and self-propelled paddy transplanting methods of paddy cultivation, respectively Singh and Rao (2012). The selfpropelled rice transplanter gave net profit of Rs 1146.00 and Rs 1319.00 per ha when annual use of machine was $300 \mathrm{~h}$ (one season) and $500 \mathrm{~h}$ (two seasons), respectively, over the manual transplanting and the payback period for investment on the transplanter was 10.23 years and 1 year when annual area covered was 20 and 80 ha, respectively Chaudhary et al., (2005). The mechanical transplanting significantly increased grain yield about 23, 37 and $63 \%$, straw yield about 17,14 and $22 \%$ and biological yield about 20, 24 and $39 \%$ over manual transplanting, dry direct seeding and direct seeding of sprouted rice in puddled conditions, respectively Singh et al., (2006). Grain yield increased with self-propelled walk behind type (9.3\%) and self-propelled four wheels type (6.7\%) transplanters over farmers practice Manesh et al., (2013). The seed rate $110 \mathrm{~g} / \mathrm{mat}$ and mat moisture of $20-25 \%$ are suitable for mats and 25-30 days nursery is best suitable for transplanting Dixit et al., (2007). Hence, the present study was conducted with an objective to compare the response of different planting system and graded levels of nitrogen on growth, yield, quality and economics of rice (Oryza sativa L.). Grain yield in both manual and mechanical transplanting remained on par with mean grain yield of 53.77 and $54.01 \mathrm{q}$ $\mathrm{ha}^{-1}$, respectively. The field capacity, field efficiency and fuel consumption of the transplanter were $0.19 \mathrm{ha} \mathrm{hr}^{-1}, 78 \%$ and 6.251 $\mathrm{ha}^{-1}$, respectively. Cost of mechanical transplanting was (₹ $789 \mathrm{ha}^{-1}$ ) as compared to 
(₹ $1625 \mathrm{ha}^{-1}$ ) in case of manual transplanting provided the machines are used for their maximum usage of 90 hectares in a year Manjunatha et al., (2009).

Machine transplanted basmati rice (Oryza sativa L.) after puddling being statistically at par with direct seeding methods, showing significantly higher values of growth and yield attributes. Yield attributes like panicle length $(26.7 \mathrm{~cm})$ and test weight $(21.6 \mathrm{~g})$ were statistically at par among different methods of establishment, but grains 141.1 panicle $^{-1}$ was significantly higher with machine transplanted basmati rice after puddling. Machine transplanted rice after puddling gave more grain yield (3.3 $\left.\mathrm{t} \mathrm{ha}^{-1}\right)$ over directseeded basmati rice with brown manuring (3.3 $\mathrm{t} \mathrm{ha}^{-1}$ ), direct seeded basmati rice without brown manuring (3.2 $\left.\mathrm{t} \mathrm{ha}^{-1}\right)$, conventional transplanted rice $\left(3.2 \mathrm{t} \mathrm{ha}^{-1}\right)$, machine transplanted rice in zero-tilled plots with brown manuring $\left(3.2 \mathrm{t} \mathrm{ha}^{-1}\right)$ and machine transplanted rice in zero tilled plots without

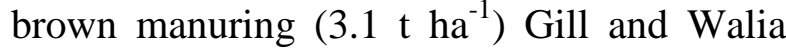
(2013). The research trial conducted by Kamboj et al., (2013) on rice to find the performance among different planting methods and output of experiment revels that in comparison with conventional puddled transplant rice (CPTR), mechanical transplanted rice (MTR) produced 3\% - 11\% higher grain yield from 2006-2010. Comparing with CPTR, non puddled MTR produced $3 \%, 5 \%, 8 \%, 6 \%$, and $11 \%$ higher grain yield in 2006, 2007, 2008, 2009, and 2010. The Crop established with mechanical transplanting method resulted in higher average grain yield of $6.66 \mathrm{t} \mathrm{ha}^{-1}$ than manual transplanting method resulted average grain yield of $5.83 \mathrm{t} \mathrm{ha}^{-1}$. The net return of manual and mechanical transplanting method was ₹ 42310 and $₹ 61080 \mathrm{t} \mathrm{ha}^{-1}$. The benefit cost ratios (BCR) were 2.24 and 1.78 for mechanical transplanting method and manual transplanting method, respectively Munnaf et al., (2014).
Graded levels of nitrogen on growth, yield, quality and economics of rice

Nitrogen is an essential plant nutrient being a component of amino acids, nucleic acids, nucleotides, chlorophyll, enzymes, and hormones. N promotes rapid plant growth and improves grain yield and grain quality through higher tillering, leaf area development, grain formation, grain filling, and protein synthesis. Nitrogen is so vital because it is a major component of chlorophyll, the compound by which plants use sunlight energy to produce sugars from water and carbon dioxide (i.e., photosynthesis). It is also a major component of amino acids, the building blocks of proteins. Among the nutrients, nitrogen is required in comparatively greater quantities than other essential elements derived from the soil. Nitrogen plays a vital role in the growth and consequently the yield of crops. Deficiency of soil nitrogen supply is one of the main limiting factors for achieving high rice yields. Hence, constant replenishment through extraneous nitrogen inputs becomes mandatory for optimal yield Qiao-gang et al., (2013).

An increase in nitrogen supply increased number of grains per panicle and 1000 grain weight, grain yield and number of tillers per hill Manzoor et al., (2006), nutritive quality of straw Nori et al., (2008) and number of panicle bearing tillers and harvest index. However, within soil the applied nitrogen undergoes several complex physical and chemical transformations which either decrease or increase the availability of nitrogen fertilizer to plant roots. The maximum yield of $4.72 \mathrm{t} \mathrm{ha}^{-1}$ was obtained at $125 \mathrm{~kg} \mathrm{~N} \mathrm{ha}^{-1}\left(\mathrm{~N}_{3}\right)$ followed by $\mathrm{N}_{2}(100 \mathrm{~kg} \mathrm{~N}$ $\mathrm{ha}^{-1}$ ) giving yield of $4.58 \mathrm{tha}^{-1}$. The minimum yield of $4.29 \mathrm{t} \mathrm{ha}^{-1}$ was obtained at the minimum nitrogen level $75 \mathrm{~kg} \mathrm{~N} \mathrm{ha}{ }^{-1}$ Ehsanullah et al., (2001). The experiment 
with 4 levels of $\mathrm{N}(0,40,80$ and $160 \mathrm{~kg} \mathrm{~N}$ $\mathrm{ha}^{-1}$ ) applied at three levels to each of the planting density $\left(20,40\right.$ and 80 hills $\left.\mathrm{m}^{-2}\right)$ it was observed that tillers plant ${ }^{-1}$ increased linearly with the increase in $\mathrm{N}$ fertilizer levels Mannujan et al., (2001). Rice cultivars Mahi Sugandha, Pusa Basmati 1 and Pusa Basmati 370 with $\mathrm{N}$ rates of $0,40,80$ or $120 \mathrm{~kg} \mathrm{~N} \mathrm{ha}^{-1}$ in Rajasthan, India during the rainy season of 1997 to determine the effects of $\mathrm{N}$ on the yield of the crops. They found that Basmati 1 give highest number of panicles $\mathrm{m}^{-2}$ (336) than others. Yield attributes of the crop increased with increasing rates of $\mathrm{N}$ Sharma and Dadhich (2003).

Application of $120 \mathrm{~kg} \mathrm{Nha}^{-1}$ recorded significantly higher $\mathrm{N}, \mathrm{P}$ and $\mathrm{K}$ uptake in rice compared to the rest of the $\mathrm{N}$ levels. Every increment of $40 \mathrm{~kg} \mathrm{~N}^{-1}$ from 0 to $120 \mathrm{~kg} \mathrm{~N}$ $\mathrm{ha}^{-1}$ increased the total $\mathrm{N}$ uptake by 49.55 , 34.30 and $27.17 \%$, total $\mathrm{P}$ uptake by 40.33 , 27.06 and $20.32 \%$ and total $\mathrm{K}$ uptake by $32.43, \quad 20.70$ and $17.25 \%$, respectively Mhaskar and Thorat (2005). Maximum paddy yield $\left(4.24 \mathrm{t} \mathrm{ha}^{-1}\right.$ ) was obtained from $175 \mathrm{~kg}$ $\mathrm{ha}^{-1}$ nitrogen application treatment which also produced highest values of number of grains panicle $^{-1}$ (130.2) along with a maximum 1000 grain weight (22.92 gm) Manzoor et al., (2006). Application of nitrogen up to $120 \mathrm{~kg}$ $\mathrm{N} \mathrm{ha}{ }^{-1}$ significantly increased the leaf area index at flowering stage. Significant increase in dry matter accumulation was recorded with application of $\mathrm{N}$ up to $90 \mathrm{~kg} \mathrm{ha}^{-1}$ Naseer and Bali (2007). Starter dose $125 \mathrm{~kg} \mathrm{~N}^{-1}$ recorded significantly higher plant height, more number of tillers hill ${ }^{-1}$ and dry matter accumulation over its lower levels Shekara and Nagarajushreedhara (2010). Increasing levels of nitrogen progressively enhanced number of panicles $\mathrm{m}^{-2}$, number of filled grains panicle ${ }^{-1}$, grain and straw yield of rice only up to $120 \mathrm{~kg} \mathrm{~N} \mathrm{ha}{ }^{-1}$ Murthy et al., (2012). Similarly Sharma et al., (2012) observed that treatment $\mathrm{N}_{120} \mathrm{P}_{45} \quad \mathrm{~kg} \mathrm{ha}^{-1}$ produced maximum panicles $\mathrm{m}^{-2}$ which was statistically at par with $\mathrm{N}_{90} \mathrm{P}_{45}$ and $\mathrm{N}_{90} \mathrm{P}_{30} \mathrm{~kg}$ $\mathrm{ha}^{-1}$. The maximum number of tillers $\mathrm{m}^{-2}$ was observed with the application of $\mathrm{N}_{120} \mathrm{P}_{45} \mathrm{~kg}$ $\mathrm{ha}^{-1}$ and maximum increase was observed at 60-90 days after transplanting. Pramanik and Bera (2013) confirmed that, among the nitrogen levels $\mathrm{N}_{200} \mathrm{~kg} \mathrm{ha}^{-1}$ gave significant higher plant height, panicle initiation, number of tillers hill $^{-1}$, total chlorophyll content, panicle length and straw yield and nitrogen levels; $\mathrm{N}_{150} \mathrm{~kg} \mathrm{ha}^{-1}$ gave significant higher number of effective tillers ${ }^{-1}$, effective tiller index, panicle weight, filled grain panicle ${ }^{-1}$, 1000 grain weight, grain yield, and harvest index as compared to $\mathrm{N}_{0}, \mathrm{~N}_{50}, \mathrm{~N}_{100}$ during both years (2010 and 2011). The highest number of tiller was obtained at the fertilizer level of $90 \mathrm{~kg} \mathrm{ha}^{-1}$ nitrogen with 526.7 tillers $\mathrm{m}^{-2}$. The maximum biologic yield was on treatment $\mathrm{N}_{4}\left(90 \mathrm{~kg} \mathrm{ha}^{-1}\right)$ with $9587 \mathrm{~kg} \mathrm{ha}^{-1}$ while the minimum one was related to $\mathrm{N}_{1}(0$ $\mathrm{kg} \mathrm{ha}^{-1}$ ) with $5348 \mathrm{~kg} \mathrm{ha}^{-1}$ Moridani et al., (2014). Nitrogen had significant positive effect and was equally superior in terms of tillers hill $^{-1}$, grains panicle ${ }^{-1}$ and straw yield. Highest number of panicle $\mathrm{m}^{-2}$ was recorded with $160 \mathrm{~kg} \mathrm{~N} \mathrm{ha}^{-1}$, however differences in filled grain panicle ${ }^{-1}$ between $120 \mathrm{~kg} \mathrm{~N}^{-1}$ and $160 \mathrm{~kg} \mathrm{Nha}^{-1}$ was statistically similar. Differences in grain yield between $160 \mathrm{~kg} \mathrm{~N}$ $\mathrm{ha}^{-1}$ (44.68 q ha ${ }^{-1}$ ) and $120 \mathrm{~kg} \mathrm{~N} \mathrm{ha}^{-1}$ (43.53 q $\mathrm{ha}^{-1}$ ) were statistically at par Sharma et al., (2014). Basmati rice yield significantly increased from $1.7 \mathrm{t} \mathrm{ha}^{-1}$ (control) to a maximum of $9.4 \mathrm{t} \mathrm{ha}^{-1}\left(90 \mathrm{~kg} \mathrm{~N} \mathrm{ha}^{-1}\right)$ before declining to $5.8 \mathrm{t} \mathrm{ha}^{-1}\left(150 \mathrm{~kg} \mathrm{~N} \mathrm{ha}^{-1}\right)$ in the order: $0<30<60<150<120<90 \mathrm{~kg} \mathrm{~N} \mathrm{ha}^{-1}$ respectively Moro et al., (2015). Similar findings are also confirmed Wani et al., (2016).

From the present study conducted on influence of different planting system and graded levels of nitrogen on growth, yield, quality and economics of rice (Oryza Sativa 
L.) it may be concluded that by practicing System of Rice Intensification and followed by $120 \mathrm{~kg}$ Nitrogen $\mathrm{ha}^{-1}$ has significantly perform better than all others planting system and levels of nitrogen for obtaining highest seed yield, stover yield, benefit cost ratio and protein content in rice. The findings are similar with various reviews which are presented in this article. This study will be helpful to researcher and farmers in increase the rice production per unit area by using different planting methods and levels of nitrogen dose. Similarly it also help to meet the daily food requirement and to supply adequate amount of Carbohydrates, protein, vitamin and minerals requirement in terms of nutritional security to farming community.

\section{Acknowledgement}

The author acknowledges the department of Agronomy, Allahabad School of Agricultural, Sam Higginbottom University of Agriculture Technology and Sciences, Allahabad (Uttar Pradesh) for providing financial support to carry out the work.

\section{References}

Adusumilli, Ravindra and Laxmi, S., Bhagya 2010. Potential of the system of rice intensification for systemic improvement in rice production and water use: the case of Andhra Pradesh, India. Paddy Water Environ. (2): 1-5.

Anitha. S and Chellappan. Mani 2011. Comparison of the system of rice intensification (SRI) recommended practices, and farmers' method of rice (Oryza sativa L.) production in the humid tropics of Kerala, India. Journal of Tropical Agriculture. 49(1-2): 64-71.

Anonymous 2005. The Hindu Survey of Indian Agriculture. 41- 46.

Anonymous 2006. The Hindu Survey of Indian Agriculture. 50-54.

Barah, B.C 2009. Economic and Ecological Benefits of System of Rice Intensification
(SRI) in Tamil Nadu. Agricultural Economics Research Review. 22(7): 209214.

Barah, B.C 2010. System of rice intensification (SRI), economic and ecological benefits of improved production practice for food security and resource conservation. Innovation and Sustainable Development in Agriculture and Food. 2(9): 1-4.

Baruah DC, Goswami NG and Saikia R 2001. Manual transplanting vs. mechanical transplanting of paddy: a techno-economic analysis in Assam. J. Agril. Engg. 38(3): 66-72.

Bouman, B.A.M 2009. How much water does rice use? Rice Today. 8 (1): 28-29.

Chapagain. T, Riseman. A and Yamaji. E 2011. Assessment of System of Rice Intensification (SRI) and Conventional Practices under Organic and Inorganic Management in Japan. Rice Science. 18(4): 311-320.

Chaudhary VP, Varshney BP and Kalra MS 2005. Self-propelled rice transplanter- a better alternative than manual transplanting. Agril. Engg. Today. 29(5\&6): 32-37.

Dass, A. and Chandra 2012. Effect of different components of SRI on yield, quality, nutrient accumulation and economics of rice (Oryza sativa) in taraibelt of northern India. Indian Journal of Agronomy. 57(3):250254.

Divya Pyngrope, Gautam Ghosh, Teruo Miura and Amit Masih 2017. Growth and Yield of Rice (Oryza sativa L.) as Influenced by Different Crop Establishment Methods and Nitrogen Levels. Int.J.Curr.Microbiol. App.Sci. 6(7): xx-xx.

Divya Pyngrope, Prasad Mithare and Gautam Ghosh 2018. Response of rice (Oryza sativa L.) as influenced by different planting systems and graded levels of nitrogen on yield, quality and economics. Journal of Pharmacognosy and Phytochemistry. 7(4): 1119-1124.

Dixit A, Khurana R, Singh J and Singh G 2007. Comparative performance of different paddy transplanters developed in India-A review. Agril. Reviews. 28(4): 262- 269.

Duttarganvi, S., Tirupataiah, Reddy, Y., Sandhyrani, Kumar, M. and Malamasuri, K 
2014. Yield and Water Productivity of Rice under Different Cultivation Practices and Irrigation Regimes. International Symposium on Integrated Water Resources Management (IWRM-2014) Feb 19-21.

Ehsanullah, Nawaz, H.M.A., Usman, $M$ and Cheema, M.S 2001. Effect of Various Levels and Methods of Nitrogen Application on Nitrogen Use Efficiency in Rice Super Basmati. International Journal of Agriculture \& Biology. 3(1).

Ganesaraja.V, Kumar, V., Veeramani, A., Veeraputhiran, R., Senthil Kumar, P., Kavitha, M.P. and Pandian, B.J 2008. Performance of system of rice intensification in farmer's fields of Sivagangai District under TN-IAMWARM Project. Paper presented in Third National Symposium on SRI in India-Policies, Institutions and Strategies for scaling up. December 1-3, TNAU, Coimbatore, Tamil Nadu, India. 211-212.

Gill, J.S and Walia, S.S 2013. Quality and grain yield of basmati rice as influenced by different establishment methods and nitrogen levels. An Asian Journal of Soil Science. 8(2): 311-318.

GOI 2015. Agriculture statistics at a glance: published by Ministry of Agriculture, Govt. of India. Http://www. Nabard.org.in.

Hossain, M.Z., Hossain, S.M.A., Anwar, M.P., Sarker, M.R.A. and Mamun, A.A 2003. Performance of BRRI Dhan 32 in SRI and Conventional Methods and Their Technology Mixes. Pakistan Journal of Agronomy. 2(4):195-200.

Hugar, A.Y., Chandrappa, H, Jayadeva, H.M., Sathish, A and Mallikarjun, G.B 2009. Comparative performance of different rice establishment methods in Bhadra command area. Karnataka J. Agric. Sci. 22(5): 992994.

Hussain, A. Bhat, M.A., Ganai, M.A., and Hussain, T 2009. Comparative performance of system of rice intensification and conventional methods of rice cultivation under Kashmir valley conditions. Environment and Ecology. 27(1): 399-402.

J. Ponni Priya, R. Veeraputhiran, V. Ganesaraja, T. Pandiselvi and B.J. Pandian 2010.
Comparative study of system of rice intensification and conventional method of rice cultivation in Madurai district of Tamil Nadu. International Journal of Agricultural Sciences. 6(2): 186-188.

Kamboj, B.R., Yadav, D.B., Yadav, A., Goel, N.K., Gill, G., Malik, R.K. and Chauhan, B.S 2013. Mechanized Transplanting of Rice (Oryza sativa L.) in Non puddled and No-Till Conditions in the RWCS in Haryana, India. American Journal of Plant Sciences. 4, 2409-2413.

Karmakar, K.G 2011. Financing Agriculture. Some issues. Yojana. Jan 28-30.

Krishna, A., Biradarpatil, N.K., Manjappa, K., and Channappagoudar, B.B 2008. Evaluation of system of rice intensification cultivation, seedling age and spacing on seed yield and quality in Samba Masuhri (BPT 5204) rice. Karnataka Journal of Agricultural Sciences. 21(1): 20-25.

Makarim, A.K., Balasubramanian, V., Zaini, Z., Syamsich, I., Ditratmadja, G.P.A., Hondoko Arafah, Wardana, I.P. and Gani 2002. System of Rice Intensification: Evaluation of seedlings age, and selected components in Indonesia. Proceedings of the International workshop on waterwise rice production, 8-11, April Losbonos, IRRI, Phillipines. 129-139.

Manesh GS, Dixit A, Singh A, Mahal JS and Mahajan G 2013. Feasibility of mechanical transplanter for paddy transplanting in Punjab. Agril. Mech. in Asia, Africa, and Latin America. 44(3): 14-17.

Manjunatha, B.N., Basavarajappa, R. and Pujari, B.T 2010. Effect of age of seedlings on growth, yield and water requirement by different system of rice intensification. Karnataka J. Agric. Sci. 23(2): 231-234.

Manjunatha, M. V., Reddy, B. G. M., Shashidhar S. D. and Joshi, V. R 2009. Studies on the performance of self-propelled rice transplanter and its effect on crop yield. Karnataka J. Agric. Sci. 22(2):385-387.

Mannujan, K., Hamid, A., Hashem, A., Hirota, O. and Khanam, M 2001. Effect of $\mathrm{N}$ fertilizer levels and planting density on growth and yield of long grain rice. Bangladesh Agricultural Science. 9(2): 19-20.

Manzoor, Z., Awan, T.H., Zahid, M.A and Faiz, 
F.A 2006. Response of Rice crop (Super Basmati) to different Nitrogen levels. $J$. Anim. Pl. Sci. 16 (1-2).

Mhaskar, N. V and Thorat, S. T. 2005. Effect of nitrogen levels on NPK uptake and grain yield of scented rice varieties under Konkan condition. Journal of Soils and Crops. 15(1): 206-209.

Moridani, M.J. and Amiri, E 2014. Effect of Nitrogen and Potassium on Yield and Yield Components of Rice cultivar "Hashemi". Indian Journal of Fundamental and Applied Life Sciences. 4(4): 417-424.

Moro, B.M., Nuhu, I.R. and Nathanial, B 2015. Effect of nitrogen rates on the growth and yield of three rice (Oryza sativa L.) varieties in rain-fed lowland in the forest agroecological zone of Ghana. International Journal of Agricultural Sciences. 5(7): 878885.

Munnaf, M.A., Hossain, M.M. and Ruma, F.Y 2014. Techno economic performance of imported kukje self-propelled rice transplanter. J. Bangladesh Agril. Univ. 12(1): 161-166.

Murthy, K.V.R., Reddy, D.S. and Reddy, G.P 2012. Response of rice (Oryza sativa L.) varieties to graded levels of nitrogen under aerobic culture. Indian Journal of Agronomy. 57 (4): 367-372.

Naseer, A.D. and Bali, A.S 2007. Influence of bio-fertilizers and nitrogen levels on transplanted rice (Oryza sativa L.) under temperate agro-climatic conditions of Jammu and Kashmir. Journal of Research. 6(1): 67-72.

Nori H., R. A. Halim, M.F. Ramlan 2008. Effect of nitrogen fertilization management practice on the yield and straw nutritional quality of commercial rice varieties. Malaysian Journal of Mathematical Science. 2(2) 61-71.

Prabha A.C.S, Thiyagarajan T.M and Senthivelu M 2011. System of Rice Intensification Principles on Growth Parameters, Yield Attributes and Yields of Rice (Oryza sativa L.). Journal of Agronomy. 10(1): 27-33.

Pramanik, K. and Bera, A.K 2013. Effect of Seedling Age and Nitrogen Fertilizer on Growth, Chlorophyll Content, Yield and Economics of Hybrid Rice (Oryza sativa L.)
International Journal of Agronomy and Plant Production. 4 (S): 3489-3499.

Qiao-gang Y., Y. Jing, Y. Shao-na, F. Jian-rong, M. Jun-wei, S. Wan-chun, J. Li-na, W. Qiang, and W. Jian-mei 2013. Effects of Nitrogen Application Level on Rice Nutrient Uptake and Ammonia Volatilization. Rice Science. 20(2): 139147.

Rajeshwar, M, and Khan, M.A.A 2008. Comparison of System of Rice Intensification (SRI) and conventional method of rice planting under NagarjunaSagar project left canal command area of Andhra Pradesh, India. Asian Journal of Soil Science. 3(1): 53-57.

Reddy, B.G.M., Ravishankar, Balaganhvi S. and Joshi V.R 2013. Nutrient management of rice (Oryza sativa) under system of rice intensification (SRI). Indian Journal of Agricultural Sciences. 83(6): 591-594.

Saha. A and Bharti. V 2010. Pollution free environment an approach. Environ. Ecol. 28: 23-29.

Saina, T 2001. More rice with less water. Approp Technol. 28(3): 8-11.

Senthil Kumar, S 2002. Productivity of hybrid rice as influenced by methods of establishment, management of water, weed and nutrients, MSc. (Ag.) Thesis.

Sharma, D., Sagwal, P.K., Singh, I. and Sangwan A 2012. Influence of Different Nitrogen and Phosphorus Levels on Profitability, Plant Nutrient Content, Yield and Quality in Basmati Cultivars. International Journal of IT, Engineering and Applied Sciences Research. 1(1).

Sharma, R., Gangwar, R.K., Yadav, V. and Kumar, R 2014. Response of Basmati rice (Oryza sativa) cultivars to graded Nitrogen levels under transplanted condition. International Journal of Research in Applied, Natural and Social Sciences. 2(9): 33-38.

Sharma, S.K. and Dadhich, L.K 2003. Response of scanted rice (Oryza sativa L.) varieties to applied nitrogen under Ghaggar flood plains of West Rajasthan. Annuals Agriculture Biological Research. 8(1) 49-50.

Shekara, B.G., Nagarajushreedhara, D 2010. Growth and yield of aerobic rice (Oryza 
sativa L.) as influenced by different levels of NPK in Cauvery command area. Journal of Maharashtra Agricultural Universities. 35(2): 195-198.

Shukla, U.N., Srivastava, V.K., Singh, S., Sen, A. and Kumar, V 2014. Growth, yield and economic potential of rice (Oryza sativa) as influenced by different age of seedlings, cultivars and weed management under system of rice intensification. Indian Journal of Agricultural Sciences. 84(5): 628-36.

Singh KK, Lohan SK, Jat AS and Rani T 2006. New technologies for planting rice for higher production. Research on crops. 7(2): 369-371.

Singh RS and Rao KVR 2012. Impact of selfpropelled paddy transplanter in Kerala. Rural Development. International Conference of Agricultural Engineering CIGR Ag Eng: agriculture and engineering for a healthier life, Valencia, Spain.

Sowmya, C.H., Ramana, M., Venkata and Kumar, Mahender 2011. Effect of system of rice cultivation, cultivars and nutrient management options on growth, yield attributes and yield of rice. Crop Research. 42(1, 2 \& 3): 1-5.

Thakur, A.K., Rath, S., Roychowdhury, S. and Uphoff, N 2010. Comparative performance of rice with system of rice intensification (SRI) and conventional management using different plant spacings. Journal of Agronomy and Crop Science. (2).

Tiwari, R.C. and Rai, M 2003. Field evaluation of puddling and transplanting equipment for rice crop under rainfed agro eco system. In: Paper presented in 37th annual convention of ISAE held at Udaipur (Rajasthan).
Uphoff, N 2002. System of Rice Intensification (SRI) for enhancing the productivity of land labour and water. J. Agric. Resource Manage. 1:43-49.

Uphoff. N 2004. System of rice intensification: an opportunity for raising productivity in the 21st century. Paper for the International Year of Rice Conference, FAO, Rome.

Veeraputhiran. R, Pandian, B.J., Nalliah Durairaj, S., Sunder Singh, J., Rajapandian, Arumugam, M, Marimuthu, M. Thiruvarasan, S. and Thiyagarajan, T.M 2008. Performance of System of Rice Intensification (SRI) in Tamirabarani Command areas of Southern Tamil Nadu. Paper presented in Third National Symposium on SRI in India-Policies, Institutions and Strategies for scaling up. (1-3): 151-153.

Vijayakumar. M, Ramesh. S, Chandrasekaran, B. and Thiyagarajan, T.M 2006. Effect of System of Rice Intensification (SRI) Practices on Yield Attributes Yield and Water Productivity of Rice (Oryza sativaL.). Research Journal of Agriculture and Biological Sciences. 2(6): 236-242.

Wani, S.A., Qayoom, S, Bhat, M.A., Lone, B.A. and Nazir, A 2016. Influence of sowing dates and nitrogen levels on growth, yield and quality of scented rice cv. Pusa Sugandh-3 in Kashmir valley. Journal of Applied and Natural Science. 8(3): 1704 1709.

Yoshida, S 1972. Physiological aspects of grain yield. Annual Review of Plant Physiology. 23:437-533.

\section{How to cite this article:}

Divya Pyngrope, Prasad Mithare and Gautam Ghosh. 2019. Influence of Different Planting System and Levels of Nitrogen on Growth, Yield, Quality and Economics of Rice (Oryza sativa L.) - A Review. Int.J.Curr.Microbiol.App.Sci. 8(01): 2161-2172.

doi: https://doi.org/10.20546/ijcmas.2019.801.226 